\title{
RESEARCH PAPER \\ ASSESSMENT OF THE WATER BALANCE OF THE BAREKESE RESERVOIR IN KUMASI, GHANA
}

\author{
M. K. Domfeh, F. O. K. Anyemedu, G. K. Anornu, K. A. Adjei and S. N. Odai \\ Civil Engineering Department, KNUST, Kumasi, Ghana \\ Emails:mardomfeh@gmail.com,fred.anyemedu@yahoo.com,anoprof@hotmail.com, \\ nanakadjei@gmail.com,snodai@yahoo.com
}

\begin{abstract}
The Barekese Reservoir constructed across the Offin River provides $80 \%$ of the total public pipe borne water supplied to the Kumasi metropolis and its environs. The reservoir was designed to produce both potable water and hydropower, however, the hydropower component has not been implemented since its construction in 1971. There is also reported land cover degradation in the catchment area which has the propensity to alter the hydrologic cycle and hence runoff into the reservoir. A 10 year water balance has been assessed for the Barekese Reservoir using an integrated Remote Sensing and GIS approach for estimation of surface runoff based on Soil Conservation Service Curve Number (SCS-CN). The SCS-CN model was calibrated against observed discharges recorded at Offinso located $10.3 \mathrm{~km}$ upstream from Barekese and the result of the calibration used to simulate runoff into the reservoir. The $S C S-C N$ model produced an $R^{2}$ value of 0.84 and an efficiency of $82.68 \%$. Monthly observed reservoir levels were used for the calibration and validation of the water balance model. The water balance model produced an $R^{2}$ value of 0.84 and an efficiency of $81.9 \%$. The monthly water budget revealed that total catchment runoff and direct precipitation respectively constituted $94.32 \%$ and $5.68 \%$ of the inflows while spilled water, water withdrawal and evaporation respectively amounted to $72.19 \%, 20.85 \%$ and $6.96 \%$ of the outflows. This result reveals that the reservoir is being underutilized. The current average production of treated water is $109,000 \mathrm{~m}^{3} /$ day but the reservoir can safely yield the design capacity of $220,000 \mathrm{~m}^{3} /$ day and an additional average hydropower of $368.6 \mathrm{~kW}$ in six months during the rainy season provided the economic analysis for the hydropower generation is found to be justifiable.
\end{abstract}

Keywords: Water balance, Barekese Reservoir, SCS-CN model, Offinso, Hydropower

\section{INTRODUCTION}

The anthropogenic disturbance of the water cycle through agriculture, deforestation and urbanization can cause considerable changes in the fluxes of runoff, groundwater table, base flow and sediment erosion (Vörösmarty and 
Sahagian, 2000; Sumarauw and Ohgushi, 2012). The Barekese Reservoir provides about $80 \%$ of the total public pipe borne water supplied to the Kumasi metropolis and its environs (Kumasi et al., 2009). The reservoir has a 15metre high, 600-metre long earth-filled dam built across the Offin River between 1967 and 1971 (Maoulidi, 2010). The characteristics of the reservoir are summarized in Table 1.

The Barekese Catchment area is currently being degraded as a result of anthropogenic activities (Kumasi et al., 2009, Boakye et al., 2008). According to Boakye et al. (2008), the trend of land use and land cover changes detected in the Barekese catchment area has potential consequences on the catchment characteristics and hydrology since land cover is a function of rainfall regime, soil conditions, geomorphology and the hydrologic cycle as a whole. These anthropogenic activities are likely to alter the water cycle and hence the runoff and sediment deposition. In spite of the key role that the Barekese Reservoir plays in the socioeconomic development of the Kumasi Me- tropolis, the water balance of the reservoir has not been assessed to aid in the management of the water resource in the face of increasing anthropogenic threats as observed by Kumasi et al. (2009) and Boakye et al. (2008).

The reservoir was designed as a multipurpose reservoir to provide both potable water and hydropower but the hydropower potential has not been utilized. This is partly because there was no economic justification for additional expenditure on a power plant due to the low electricity tariffs and the availability of enough hydropower from Akosombo at the time of construction and hence, the hydropower phase was not implemented (Dernedde and OfosuAhenkorah, 2002).

The country is currently being plagued with frequent power outages causing the country to lose between $2 \%$ to $6 \%$ of Gross Domestic Product (GDP) annually (Acheampong and Ankrah, 2014). In a bid to deal with the prevailing power interruptions in the country, the country has resorted to thermal power genera-

Table 1: Reservoir characteristics

\begin{tabular}{ll}
\hline & Reservoir Characteristics \\
\hline Catchment area & $906\left(\mathrm{~km}^{2}\right)$ \\
Reservoir Capacity & \\
Gross (G) & 35.3 million $\mathrm{m}^{3}$ \\
Dead Water (DW) & 1.55 million $\mathrm{m}^{3}$ \\
Design Useable (DU = G-DW) & 33.75 million m \\
Current Capacity & 24.6 million $\mathrm{m}^{3}$ \\
Earthfill Embankment Crest Level & $223.69 \mathrm{masl}$ \\
Earthfill Embankment Crest Length & $526 \mathrm{~m}$ \\
Spillway Length & $77 \mathrm{~m}$ \\
Earthfill Embankment Crest Width & $6 \mathrm{~m}$ \\
Height of Dam (max above river bed level) & $18.5 \mathrm{~m}$ \\
Height of Dam (max above foundation level) & $21.5 \mathrm{~m}$ \\
Spillway Crest Level & 220.9 masl \\
Normal Retention Water Level & 220.9 masl \\
Maximum Flood Water Level & 222.4 masl \\
\hline
\end{tabular}

Source: (Hooijer and Track, 2009) 
Water balance of the Barekese Reservoir ...

tion which is also far expensive compared to hydropower generation. Mini-hydro power generation for rural electrification has been recommended by many authors including Miller et al. (2011) and Arthur (2014) as a means to alleviate the prevailing power crises. Approximately 70 sites, with a total potential of $800 \mathrm{MW}$, have been identified for small hydropower generation in Ghana; however, none of these sites have been utilized up-to-date (Miller et al., 2011). The implementation of the minihydropower facility at the Barekese Headworks could serve as a boost to catalyze the implementation of similar projects in other potential sites in the country. Mini-hydropower facilities generally result in rapid socio-economic development of surrounding communities.

Water balance analysis is a highly effective tool that relates local climate, geological, hydrological and land use conditions to the quantity of water available for groundwater recharge and surface runoff (Adie et al., 2012).

This study assesses the water balance of the Barekese Reservoir to aid efficient planning, management and decision making on the use of water in the reservoir. The output of the water balance provided an opportunity for the assessment of the hydropower potential of the reservoir. In this regard, the paper highlights how the water balance model could be used to optimize the benefits from a multi-purpose reservoir using the Barekese Reservoir as a case study.

\section{RESEARCH METHODOLOGY}

\section{Study area}

The Barekese Reservoir is located $19 \mathrm{~km}$ North -West of Kumasi between $06^{\circ} 51.11^{\prime} \mathrm{N}$; $010^{\circ} 42.10^{\prime} \mathrm{W}$ and $06^{\circ} 50^{\prime} \mathrm{N}$; $010^{\circ} 39.88^{\prime} \mathrm{W}$ on the Offin River in the Ashanti Region. Fig. 1 shows the location of the reservoir, dam and the catchment area with River Offin drainage network.

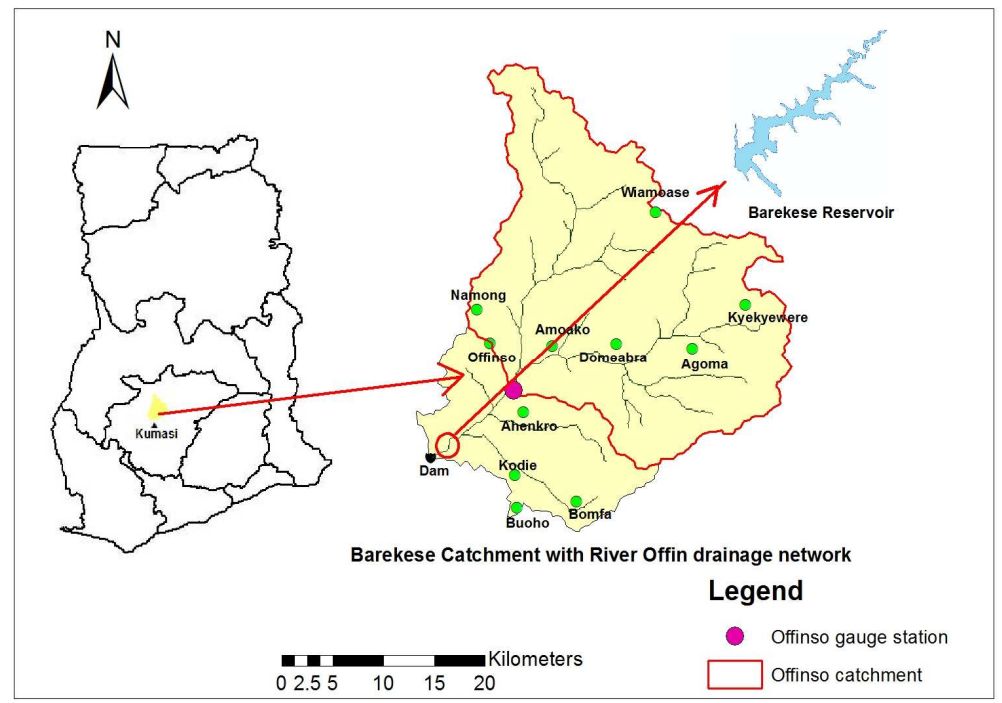

Fig. 1: Location of Barekese Reservoir, dam and catchment area with River Offin drainage network

Journal of Science and Technology @ KNUST December 2015 


\section{Anyemedu et al.}

The Barekese Reservoir lies within the River Offin Basin. The area has a semi-humid tropical climate with two rainy seasons: the main season from April to July and the minor season from September to October. The mean annual rainfall in the basin is about $1,368 \mathrm{~mm}$. The maximum temperature ranges between $30.2^{\circ} \mathrm{C}$ to $31.5^{\circ} \mathrm{C}$ whilst the mean minimum temperature ranges between $21.1^{\circ} \mathrm{C}$ to $22.1^{\circ} \mathrm{C}$. The average relative humidity in the area is about $79 \%$ (Gyampoh et al., 2009, Turner et al., 1996).

The geology of the Barekese catchment area consist of Upper Voltain and Dahomeyan. The Upper Voltain underlie 3\% of the area and consists mainly of sandstone while Dahomeyan underlie $97 \%$ of the area and consists of granitoid undifferentiated. The geology of the catchment area shown on Fig. 2 was prepared from a shapefile of the geology of Ghana produced by the Geological Survey Department of Ghana.

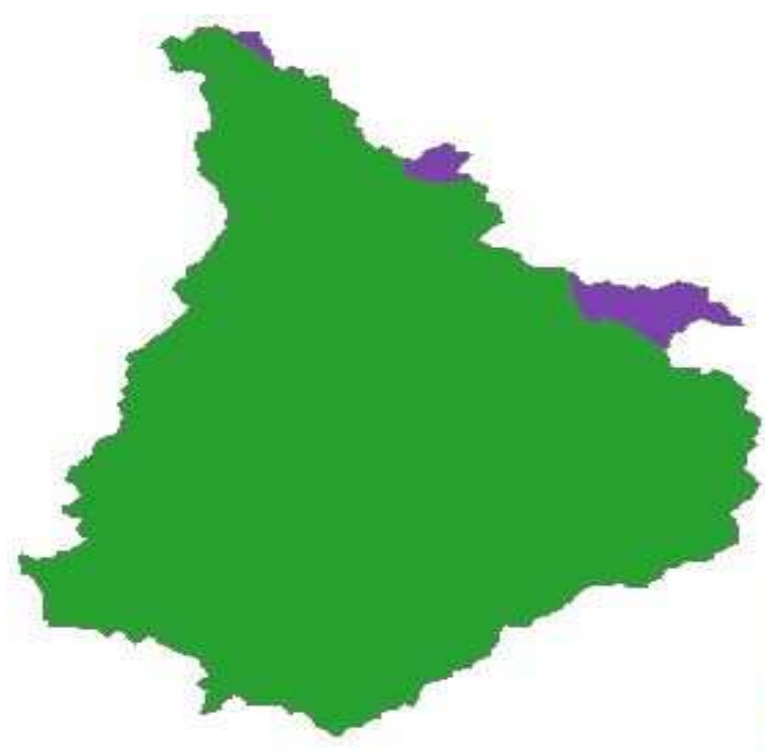

Legend

Geology_1

ERA_SERIES

Dahomejan

Upper Voltaian.

Fig. 2: The geology of Barekese catchment

Journal of Science and Technology @ KNUST December 2015 
Water balance of the Barekese Reservoir ...

season and fluctuate in water level during the rainy season. River Offin after Barekese joins the Upper Tano River along the Yenahin Range Watershed (Adu, 1992). The drainage network of River Offin at Barekese catchment area is shown in Fig. 1.

Water Balance Analysis

Model formulation of the water balance components

A generalized water balance model of a reservoir describes how water levels in a reservoir respond to various simulated inflow and outflow scenarios (Yeung, 2005). The generalized form of the model is given by:

$\Delta S=\Sigma R(t)-\Sigma W-\Sigma S_{p}+\Sigma(P-E) A_{s} \pm G(t)$

Where $\Delta S$ is the change in the stored water volume in the reservoir, $t$ is the time interval (monthly), $\Sigma R$ is the total monthly runoff into the reservoir, $\Sigma W$ is the total monthly water withdrawal, $\Sigma S_{p}$ is the total monthly spilled water, $P$ is the monthly rainfall onto the reservoir, $E$ is the monthly evaporation from the reservoir surface, $A_{s}$ is the surface area of the reservoir computed from the water level-area curve and $G$ is the net monthly groundwater inflow into the reservoir.

Model reduction of the water balance components

Groundwater contribution to a reservoir over a long period is assumed to be negligible (Andreini et al., 2000). Hence, the net groundwater contribution into the reservoir is considered minimal and therefore negligible $(G=0)$ relative to the other outflows and inflows. Besides, there exists no information on the net groundwater contribution into the reservoir. The simplified model then becomes:

$\Delta S=\Sigma R(t)-\Sigma W-\Sigma S_{p}+\Sigma(P-E) A_{s}$

The components of the reservoir water balance model are shown in Fig. 3.

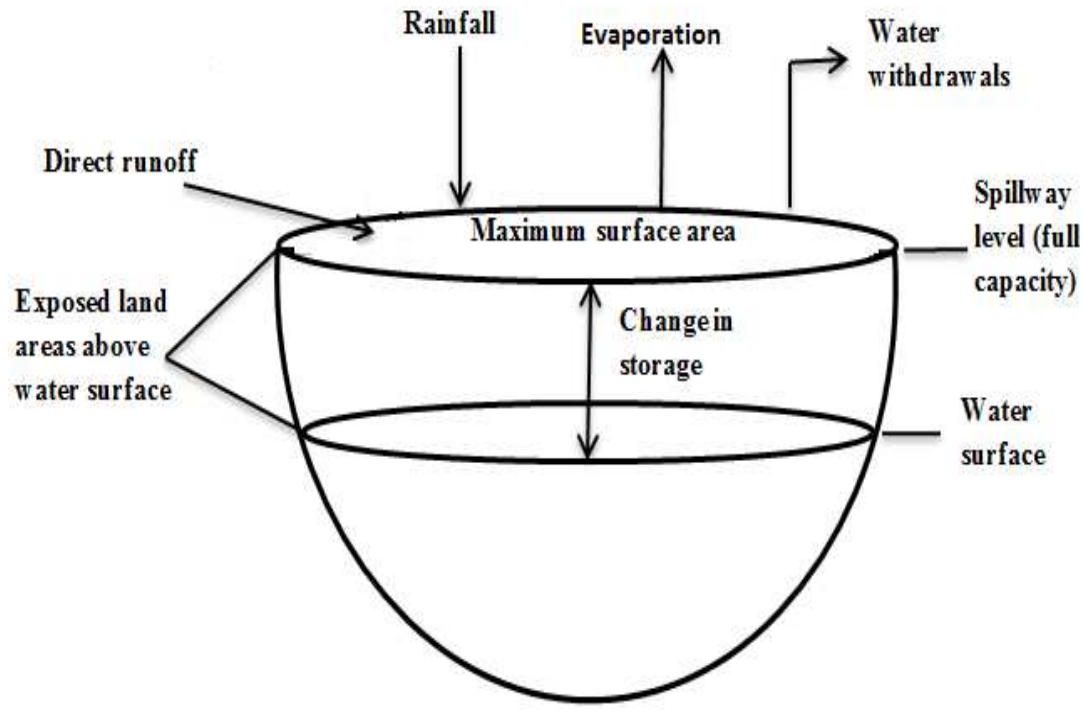

Fig. 3: Schematic view of the water budget of Barekese Reservoir (adopted from Yeung, 2005) 


\section{Anyemedu et al.}

Determination of components of the water balance

\section{Precipitation}

The Ghana Meteorological Agency operates meteorological stations at Barekese, Offinso and Kumasi but Offinso and Barekese stations have not been operational since 2005 as a result of lack of personnel and adequate equipment. Kumasi Meteorological Station, on the other hand has up-to-date meteorological records. The monthly precipitation correlation between Kumasi and Offinso records was 0.71 for the period spanning 1990 to 2004 while the correlation between that of Kumasi and Barekese was 0.65 spanning 1993 to 2004. The absence of a very strong correlation could be attributed to inadequate monitoring of operations and records at the Offinso and Brekese meteorological stations. Under this prevailing condition, the study adopted the monthly precipitation records for Kumasi.

Catchment delineation, gauging and discharge measurement

The two catchment areas (Offinso and Barekese) were delineated in ArcGIS using SRTM DEM downloaded from GLCF at the University of Maryland, USA. The study employed the use of digitized soil map (shapefile) of Ghana produced by the Soil Research Institute of CSIR and the delineated catchment areas to prepare soil map for the catchment areas. The reclassification of the soil types into Hydrological Soil Group (HSG) was based on the
FAO soil group classification as provided in Table 2.

Land cover maps for December 1986 and May 2007 were prepared using Landsat images in Erdas Imagine Software and merged with the soil maps in ArcGIS to generate curve number maps for Barekese and Offinso catchment. The unsupervised classification method was used for the land cover classification. The procedure for catchment delineation and derivation of curve number map is illustrated in Fig. 4. Since only few satellite images were used for the study, land cover change was assumed to be linear and hence the need to interpolate the land cover change for estimation of the weighted curve number for unknown periods in MS Excel. The SCS-CN relation given below was used to compute the runoff:

$P_{e}=\frac{(p-0.25)^{2}}{p+0.85}$

$S(\mathrm{~cm})=\frac{25.40}{C N}-25.4$

$C N_{w}=\frac{z_{i=1}^{n} C N_{i} A_{i}}{z_{i=1}^{n} A_{i}}$

Where $P_{e}$ is the excess rain or direct runoff, $\mathrm{S}$ is the potential maximum retention, $C N$ is the curve number. The estimation of the weighted

Table 2: Soil reclassification table

\begin{tabular}{|c|c|c|}
\hline $\begin{array}{c}\text { FAO Soil } \\
\text { Class } \\
\end{array}$ & Soil Composition & $\begin{array}{l}\text { Reclassified SCS-CN } \\
\text { HSG }\end{array}$ \\
\hline Acrisols & sand, loamy sand and sandy loam soils & $\mathrm{A}$ \\
\hline Leptosols & sandy clay loam soils & $\mathrm{C}$ \\
\hline Lixisols & $\begin{array}{l}\text { clay loam, silty clay loam, sandy clay, silty clay and } \\
\text { clay soils }\end{array}$ & $\mathrm{D}$ \\
\hline
\end{tabular}

Source: USDA Soil Conservation Service, 1972

Journal of Science and Technology @ KNUST December 2015 


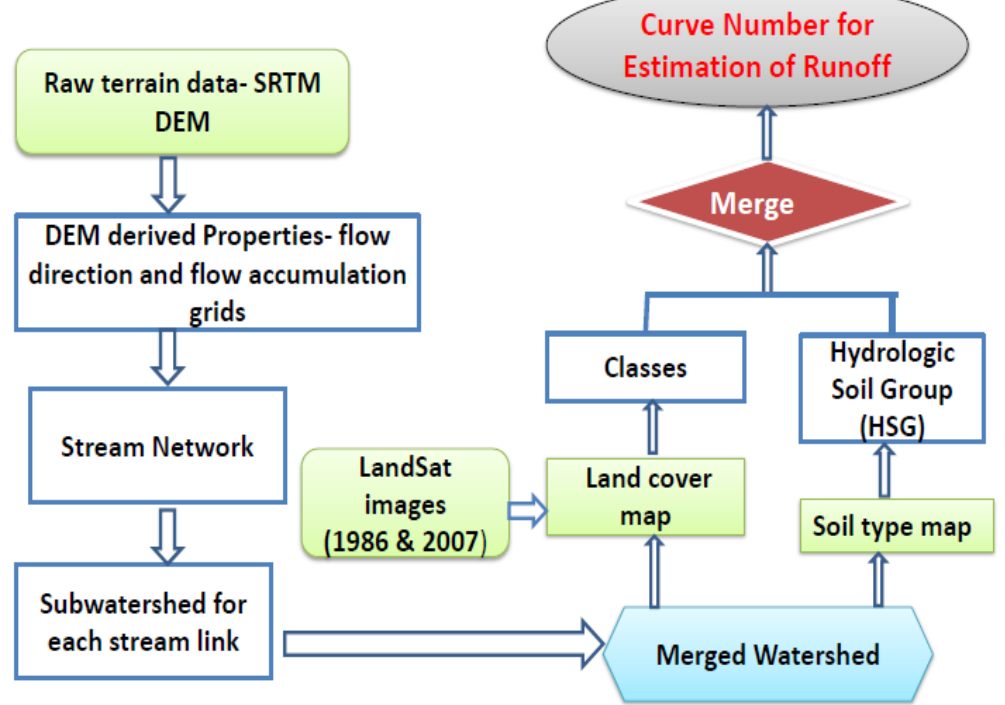

Fig. 4: Procedure for catchment delineation and derivation of curve number

$C N_{W}$ value was based on the $C N$ values for normal antecedent moisture conditions. $C N_{w}$ is the weighted curve number, $C N_{i}$ is the curve number for land cover type, $A_{i}$ refers to the area with curve number $C N_{i}$ whilst $\sum_{i=1}^{n} A_{i}$ is the

total area of the catchment (Suphunvorranop, 1985, Chow et al., 1998, Shadeed and Almasri, 2010, Kumar et al., 2010).

Runoff into the reservoir from the Barekese Catchment is only monitored at Offinso, located at $10.3 \mathrm{~km}$ upstream from Barekese Reservoir, while the contribution from the remaining portion of the catchment area is not monitored (Fig. 1). The Offinso hydrological station is located at $06^{\circ} 53^{\prime} \mathrm{N}$ and $01^{\circ} 38^{\prime} \mathrm{W}$. Since there is no gauge station on the reservoir, an SCS-CN rainfall-runoff model calibrated at Offinso was used to derive the monthly simulated runoff into the reservoir at Barekese. After obtaining the monthly runoffs from the SCS curve number model at Offinso Gauge Station, it was re- alized that the model was over-predicting the surface runoff hence the need to calibrate the model. The calibration was done by adjusting the model input parameter (weighted curve number) to ensure best simulated estimates for the observed stream flow at Offinso. In accordance with the Klemes split sample test, the first five years (2001-2005) was used for the calibration while the last five years (20062010) was used for the validation. The adjustment was subsequently applied to the weighted curve number estimated for the larger Barekese catchment to determine the simulated runoff into the Barekese Reservoir.

\section{Evaporation}

Evaporation from the water surface is not monitored at the headworks. The Penman method has been found suitable for evaporation estimation under any climatic conditions and for a time scale as long as one month (Kebede et al., 2006). This evaporation model was therefore adopted for the study. The Penman evaporation is given by: 
41 Anyemedu et al.

$E=\frac{A H_{n}+E_{a} \gamma}{A+\gamma}$

Where $A$ is the slope of the saturation vapour pressure verses temperature curve at the mean air temperature, $\mathrm{mm}$ of $\mathrm{Hg} /{ }^{\circ} \mathrm{C}, \gamma$ is the Psychrometric constant $=0.49 \mathrm{~mm}$ of $\mathrm{Hg} /{ }^{\circ} \mathrm{C}, H_{n}$ is the net radiation, $\mathrm{mm}$ of evaporable water per day, $E_{a}$ is the parameter including wind velocity and saturation deficit.

$H_{n}=H_{a}(1-r)\left(a+b \frac{n}{N}\right)-\sigma T_{a}^{4}\left(0.56-0.092 \sqrt{e_{a}}\right)\left(0.1+0.9 \frac{n}{N}\right)$

Where $H_{a}$ is the Incident (Extraterrestrial) solar radiation outside the atmosphere on a horizontal surface ( $\mathrm{mm}$ of evaporable water per day), $a$ is a constant depending on the latitude $\phi$

$a=0.29 \cos \phi$

$b$ is a constant with an average value of $0.52, n$ is the actual duration of bright sunshine, hrs, $N$ is the maximum possible hours of bright sunshine (hrs), $r$ is the reflection coefficient (albedo), $\sigma$ is the Stefan-Boltman constant = $2.01 \times 10^{-9}$, is the mean air temperature in degree kelvin $=273+{ }^{\circ} \mathrm{C}$

$E_{a}=0.35\left(1+\frac{U_{a}}{160}\right)\left(e_{w}-e_{a}\right)$

$E_{a}$ is the parameter including wind velocity and saturation deficit, $U_{2}$ is the mean wind speed at $2 \mathrm{~m}$ above ground surface ( $\mathrm{km} / \mathrm{day}), e_{w}$ is the saturation vapour pressure at mean air temperature ( $\mathrm{mm}$ of $\mathrm{Hg})$.

$e_{w}=4.584 \exp \left(\frac{17.27 t}{237.3+t}\right) \mathrm{mm}$ of $\mathrm{Hg}$

$\mathrm{t}$ is the temperature in ${ }^{\circ} \mathrm{C}, e_{w^{-}} e_{a}$ is the vapour deficit, $e_{a}$ is the actual vapour pressure

$R H=100 \frac{\theta_{a}}{\varepsilon^{\circ}(t)}$

$R H$ is the Relative humidity.
Meteorological data such as temperature, humidity and evaporation used to obtain the variables in the Penman Equation were obtained from Ghana Meteorological Agency, Kumasi. In situations where data such as slope of the saturation vapour pressure verses temperature curve, incident solar radiation, maximum possible hours of bright sunshine and reflection coefficient were not available, standard data from FAO Irrigation and drainage paper 56 by Allen et al. (1998) based on other primary meteorological data for the region were used.

\section{Withdrawals}

Information on monthly withdrawals from the reservoir was obtained from Ghana Water Company Limited (GWCL) Barekese Headworks Station, Kumasi. Withdrawals are estimates from pumping hours since there is no gauge in place for such function.

\section{Spill}

There is no monitoring of the quantity of water that leaves the spillway of the reservoir. Monthly spills were therefore estimated as excess of the storage capacity.

\section{Hydropower generation potential of the reservoir}

The hydropower potential of the reservoir was assessed as excess of the simulated discharge required to meet the design capacity of $220,000 \mathrm{~m}^{3} /$ day of treated water with allowance for losses during treatment. GWCL estimates losses during treatment to be $5 \%$ of the total raw water (Antwi, 2005). The head $H$ of the reservoir is $12 \mathrm{~m}$ (Dernedde and OfosuAhenkorah, 2002). British Hydropower Association estimates the overall system efficiency, $\eta$, to be in the range of $60 \%-80 \%$. An average value of $70 \%$ was used for the computation.

If, $Q$, is the rate of flow $\left(\mathrm{m}^{3} / \mathrm{s}\right)$ of water that is available for hydropower generation, and the reservoir has a head, $H$ in meters, $\gamma$ is the unit weight of water and $\eta$ is the overall system efficiency then: 
i) Water Power Potential, $P=\gamma \times Q \times H$

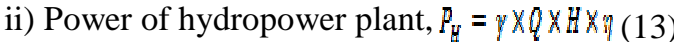

\section{RESULTS AND DISCUSIONS}

\section{Catchment areas and land cover change}

The estimated area of Barekese catchment and Offinso catchment are $893.26 \mathrm{~km}^{2}$ and $685 \mathrm{~km}^{2}$ respectively. Fig. 1 illustrates the two catchment areas. The soils found on the Barekese catchment area are Acrisols, Leptosols and Lixisols with percentage area coverage of $90.96 \%$, $5.78 \%$ and $3.26 \%$ respectively. The map showing the soil types on Barekese catchment is depicted in Fig. 5. Since few satellite images were available for this study, satellite images for 1986 and 2007 were used. Land cover maps produced for the Barekese catchment area for 1986 and 2007 using the unsupervised classifcation are illustrated in Figs. 6 and 7 respect-

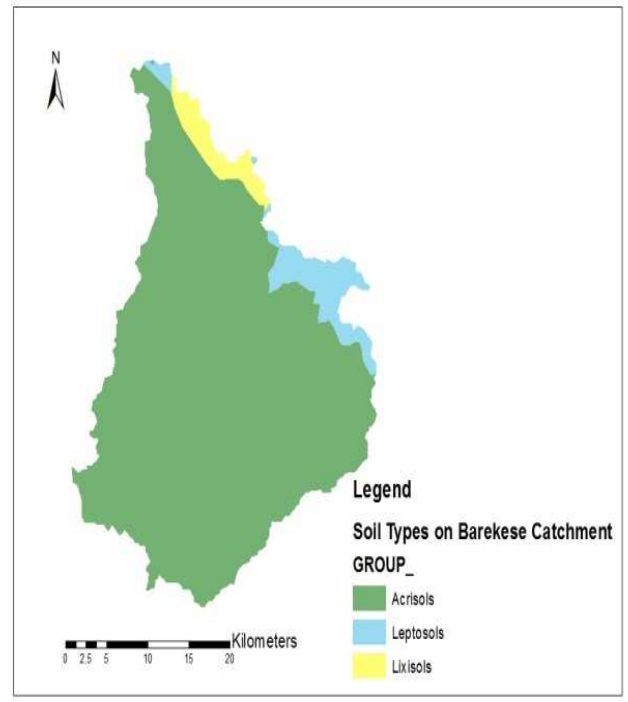

Fig. 5: Map showing the soil types on the Barekese catchment tively. The results of the land cover classification reveal land cover degradation in the study area. From Table 3, open forest in the Barekese catchment area has decreased significantly by $44.85 \%$ within the period from 1986 to 2007 while closed forest has increased by $3.58 \%$. The water body has reduced by $59.10 \%$. Farmland/grassland/shrubs, open area and settlements have appreciably increased by $29.99 \%$, $29.79 \%$ and $48.01 \%$ respectively within the same period. The merging of the land cover map and the soil map in ArcGIS produced the curve number map for the Barekese catchment area which is illustrated in Fig. 8. The curve number map was used for the estimation of the weighted curve number for the computation of surface runoff using the SCS-CN model.

\section{Calibration of surface runoff}

Fig. 9 illustrates the calibrated and validated discharge with observed discharge. The SCS

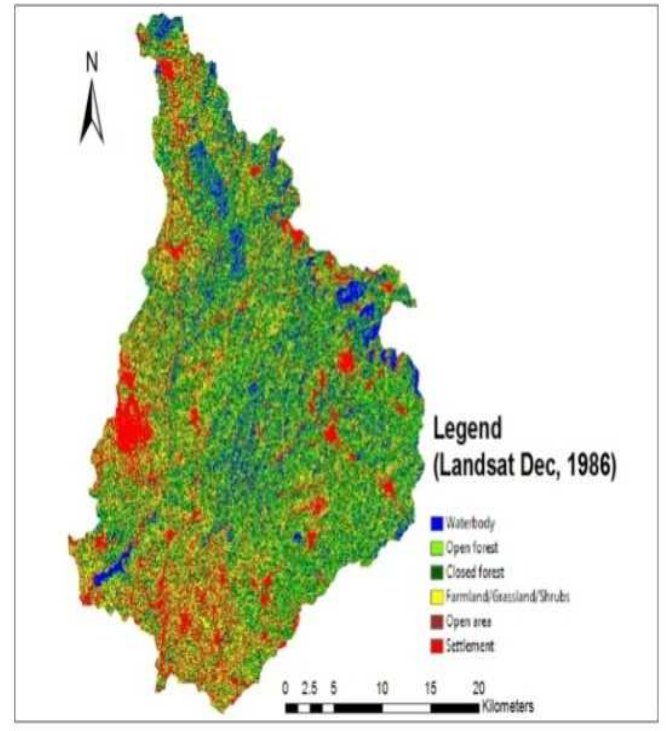

Fig. 6: Land cover map for Barekese catchment, 1986 
model produced an $\mathrm{R}^{2}$ value of 0.84 and an efficiency of $82.68 \%$. This indicates a good performance with observed data.

\section{Precipitation (Rainfall)}

Monthly distribution of rainfall for the period of study is illustrated in Fig. 10. The catchment area falls under a region with a bimodal rainfall

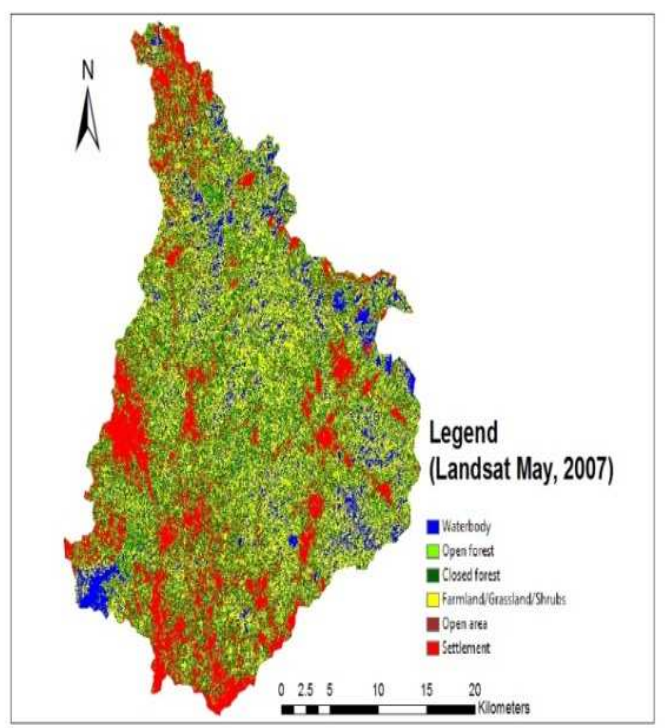

Fig. 7: Land cover map for Barekese catchment, 2007 pattern which peaks from April to July in the major season and from September to October in the minor season. The maximum average monthly precipitation recorded in June was $204.3 \mathrm{~mm}$ while the minimum average monthly precipitation recorded in January was $19.9 \mathrm{~mm}$. The mean annual precipitation was $1538.2 \mathrm{~mm}$.

\section{Water Withdrawal}

Monthly withdrawal for water supply from 2001 to 2010 ranged between $2,095,070 \mathrm{~m}^{3}$ $2,114,596 \mathrm{~m}^{3}$ with an average of $2,104,891 \mathrm{~m}^{3}$ per month. Monthly water withdrawal from 2001 to 2010 is illustrated in Fig. 11.

Monthly pan evaporation estimated using the Penman Evaporation Model shows a fluctuation within the period which ranged between $5.42 \mathrm{~mm}$ per day to $4.43 \mathrm{~mm}$ per day with an average of $4.84 \mathrm{~mm}$ per day. The estimated monthly evaporation using Penman Evaporation Model is illustrated in Fig. 12.

Calibration and validation of the water balance model

A monthly routing of the outflows and inflows was performed using the water balance model in Microsoft Excel. There has been a reduction in reservoir capacity from an initial gross capacity of 35.3 million $\mathrm{m}^{3}$ in 1971 to a capacity of 24.6 million $\mathrm{m}^{3}$ in 2009 (Hooijer and Track, 2009). Volume-elevation curves for 1999 and 2009 were used because of the changing reser-

Table 3: Land cover change in the Barekese catchment area (1986-2007)

\begin{tabular}{lllllll}
\hline Land cover & $\begin{array}{l}\text { Area in } \\
\mathbf{1 9 8 6}(\mathbf{h a})\end{array}$ & $\begin{array}{l}\text { Percentage } \\
\text { of total area } \\
\text { in 1986 }\end{array}$ & $\begin{array}{l}\text { Area in } \\
\mathbf{2 0 0 7}(\mathbf{h a})\end{array}$ & $\begin{array}{l}\text { Percentage } \\
\text { of total area } \\
\text { in 2007 }\end{array}$ & $\begin{array}{l}\text { Change } \\
\text { in Area } \\
\text { (ha) }\end{array}$ & $\begin{array}{l}\text { Percentage } \\
\text { change }\end{array}$ \\
\hline Waterbody & 5454.66 & 6.09 & 2231.01 & 2.49 & -3223.65 & -59.10 \\
$\begin{array}{l}\text { Open Forest } \\
\text { Closed Forest }\end{array}$ & 21278.68 & 23.76 & 11735.19 & 13.10 & -9543.49 & -44.85 \\
$\begin{array}{l}\text { Farmland/Grassland/ } \\
\text { Shrubs }\end{array}$ & 24810.42 & 27.70 & 25698.51 & 28.70 & 888.09 & 3.58 \\
$\begin{array}{l}\text { Open Area } \\
\text { Settlement }\end{array}$ & 14475.49 & 23.20 & 27005.22 & 30.16 & 6229.73 & 29.99 \\
\hline
\end{tabular}


Water balance of the Barekese Reservoir ... 44

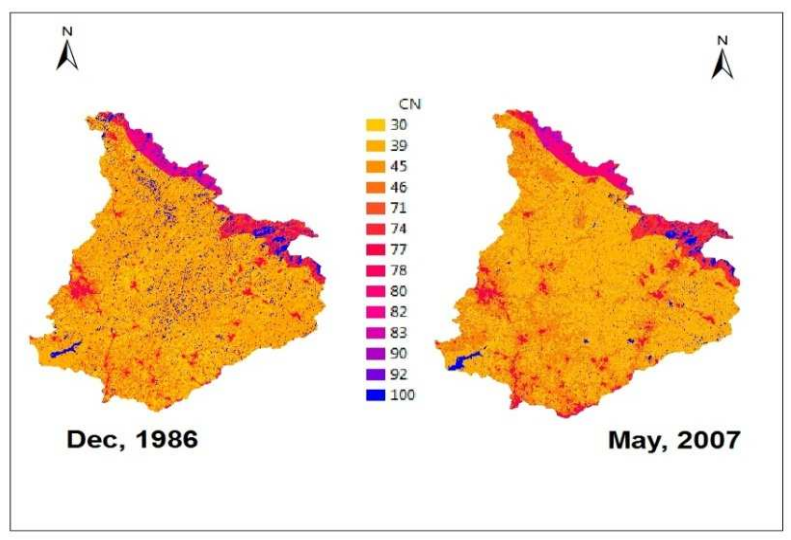

Fig. 8: Curve number map for Barekese catchment area

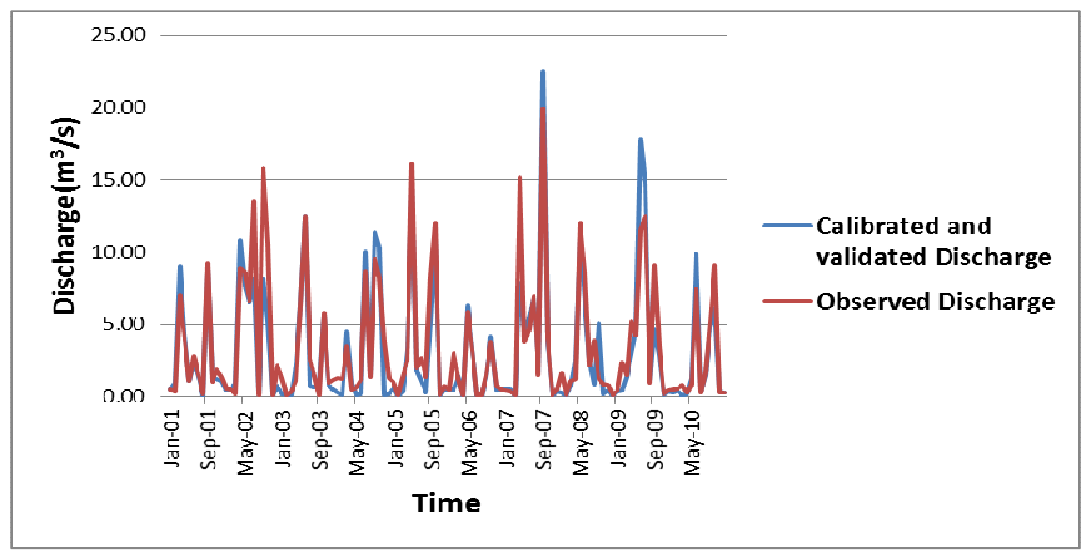

Fig. 9: Calibrated and validated discharge with observed discharge

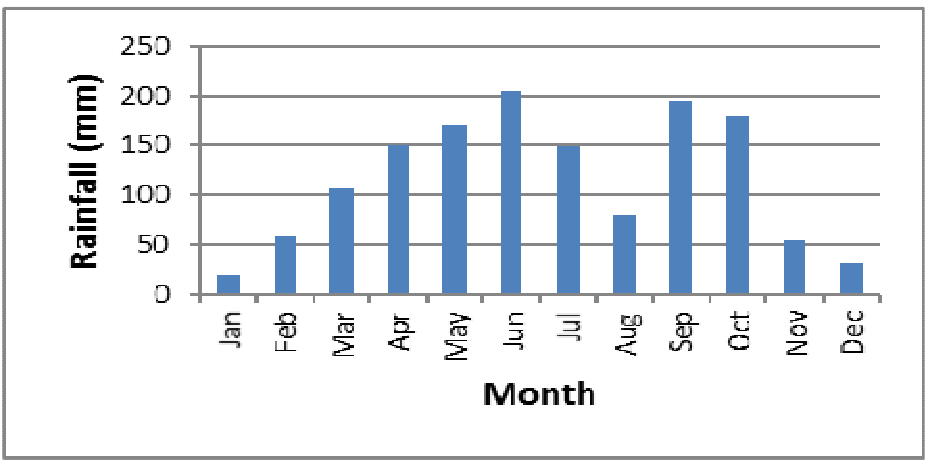

Fig. 10: Average monthly rainfall for Kumasi (2001-2010)

Journal of Science and Technology (C) KNUST December 2015 


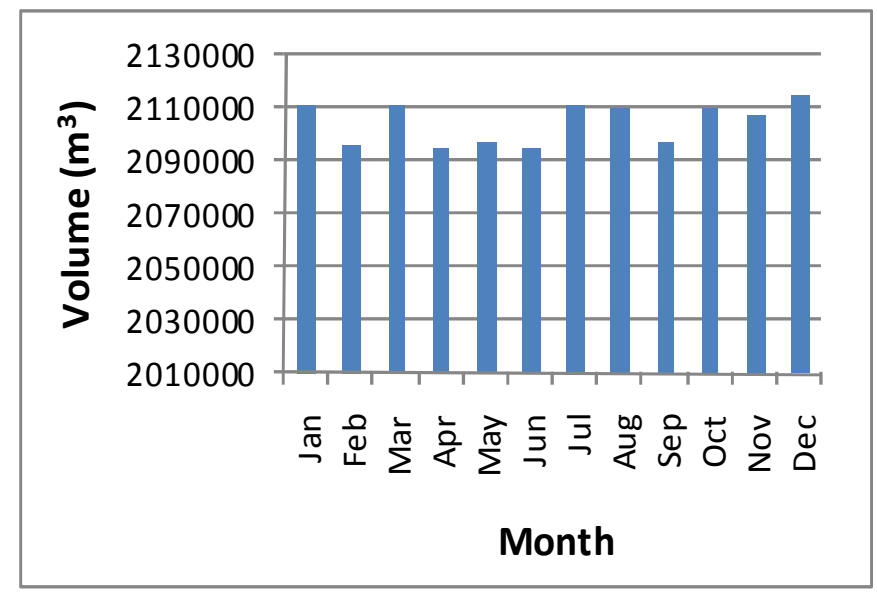

Fig. 11: Average monthly water withdrawal (2001-2010)

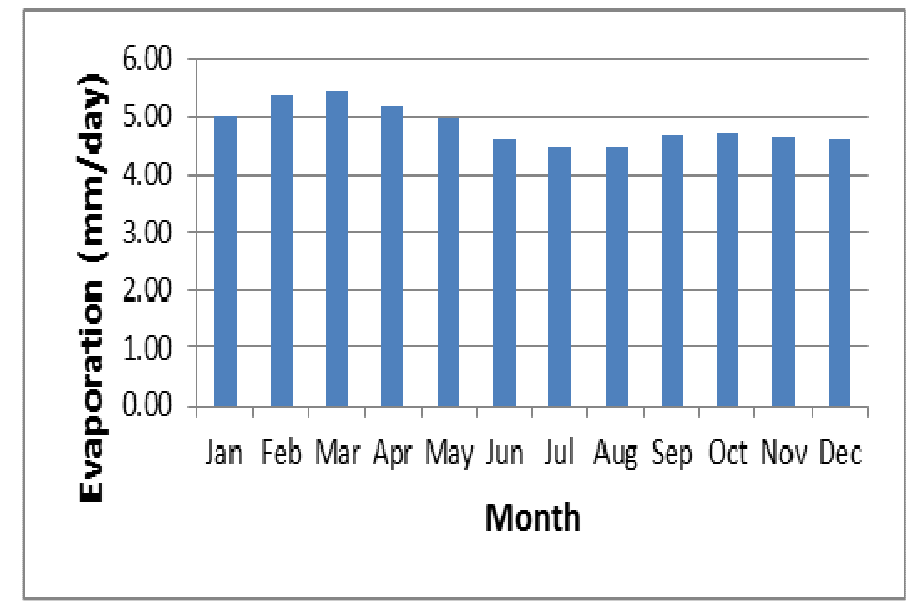

Fig. 12: Estimated average monthly evaporation for Kumasi using the Penman Evaporation Model (2001-2010)

voir storage as a result of sedimentation activities with time. The estimated reservoir capacity for the period 2001-2005 using Brune's and Brown's approach was generally comparable with storage capacity from the volumeelevation curve for 1999 and hence the curve was used for the calibration period (2001-2005) and that for 2009 fitted well for the validation period (2006-2010). Literature on Brune's and Brown's approach for estimation of reservoir capacity is found in Jothiprakash and Garg (2008) and Adwubi et al. (2009). Elevation 220.9 m.a.s.l. is the spillway crest level and hence considered as spill level in the simulation. It was realized that the simulated reservoir levels were generally slightly lower than 
Water balance of the Barekese Reservoir ... 46

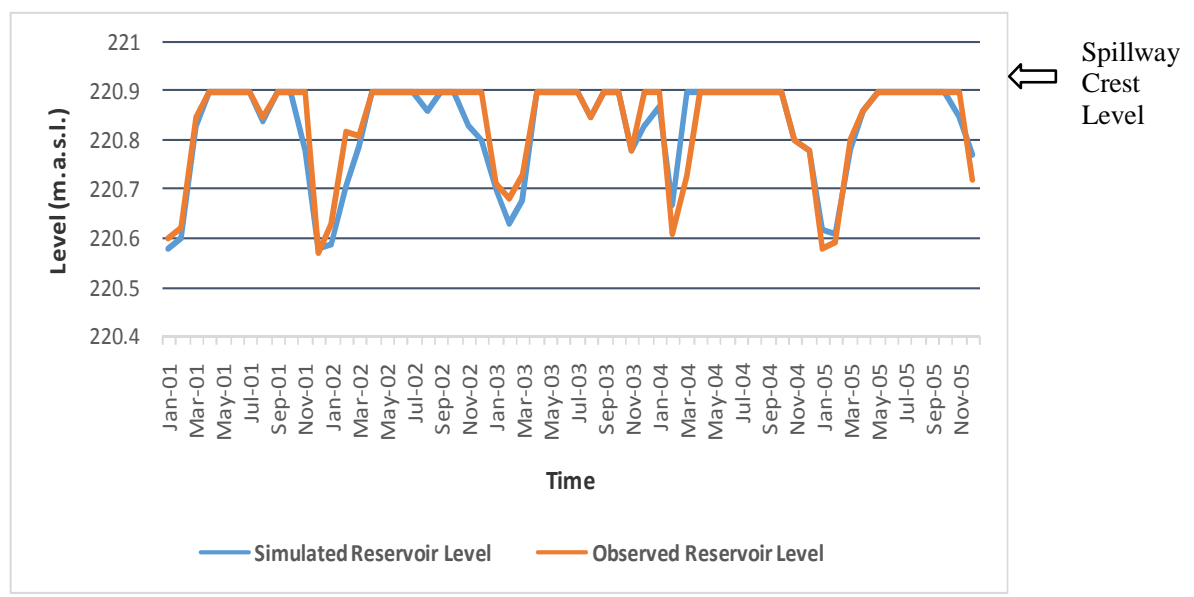

Fig. 13: Simulated and observed reservoir levels for the calibration period (2001-2005)

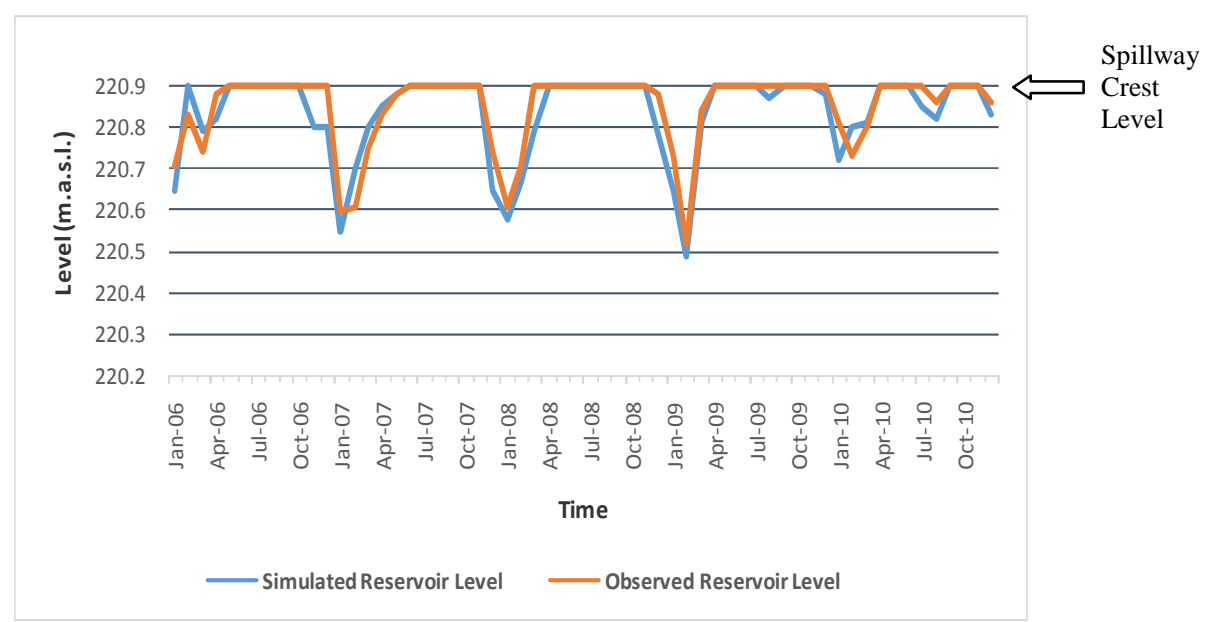

Fig. 14: Simulated and observed reservoir levels for the validation period (2006-2010)

the observed reservoir levels hence the need to adjust other inputs of the water balance model in order to simulate as close as possible to the observed reservoir levels.

Calibration involved adjusting correction coefficients associated with precipitation, evaporation and withdrawal by try-and-error method to fit simulated reservoir volumes to observed reservoir volumes. After calibration, the water balance model had $\mathrm{R}^{2}$ of 0.86 and an efficiency of $84.8 \%$. Fig. 13 illustrates the simulated and observed reservoir levels for the calibration period (2001-2005). The calibrated model was used to simulate runoff over an independent period outside the calibration period. The vali- 
dated model has $\mathrm{R}^{2}$ of 0.83 and an efficiency of $78.2 \%$. Fig. 14 illustrates the simulated and observed reservoir levels for the validation period (2006-2010). The performance of the water balance model is provided in Table 4 . The water balance model produced an $\mathrm{R}^{2}$ of 0.84 and an efficiency of $81.9 \%$ for the entire period (2001-2010). The overall performance of the water balance could be described as being satisfactory. There exists a strong correlation between the measured and simulated reservoir levels.
From Fig. 15, it is observed that the water resource potential of the reservoir is being underutilized. From Table 5, withdrawal for water supply constituted only about $20.85 \%$ of the outflows while the amount of water spilled constituted $72.19 \%$. The reason for the large volumes of spill could be attributed to the underutilization of the facility for water supply and hydropower. The design capacity of the Barekese Headwork for treated water production is $220,000 \mathrm{~m}^{3} /$ day (Maoulidi, 2010) but the

Table 4: Performance of Barekese reservoir water balance model

\begin{tabular}{lll}
\hline Period & $\mathbf{R}^{2}$ & Efficiency (\%) \\
\hline Calibration (2001-2005) & 0.86 & 84.8 \\
Validation (2006-2010) & 0.83 & 78.20 \\
Entire period (2001-2010) & 0.84 & 81.90 \\
\hline
\end{tabular}

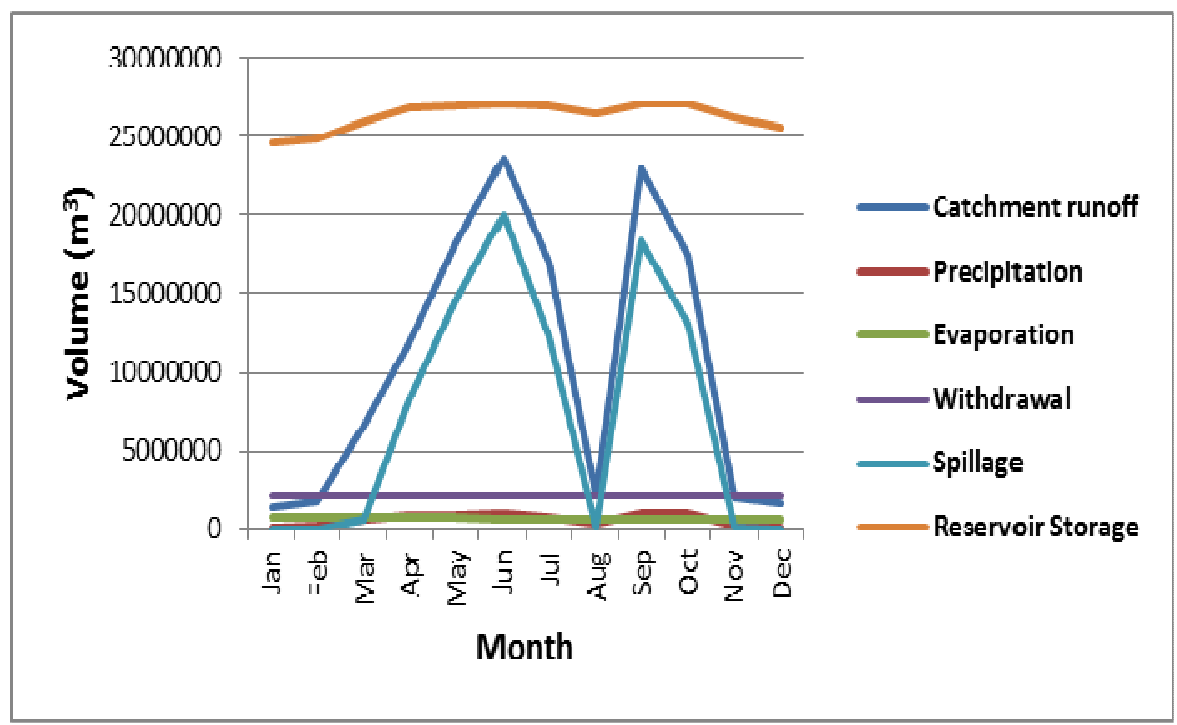

Fig. 15: Monthly reservoir volume and water budget

Journal of Science and Technology (C) KNUST December 2015 
Table 5: Water budget of the Barekese Reservoir

\begin{tabular}{|c|c|c|c|c|}
\hline \multicolumn{2}{|c|}{ Inflows } & \multicolumn{3}{|c|}{ Outflows } \\
\hline \multicolumn{2}{|c|}{ (percentage of total inflows) } & \multicolumn{3}{|c|}{ (percentage of total outflows) } \\
\hline Total runoff & Direct rainfall & Evaporation & Water withdrawals & Spill \\
\hline 94.32 & 5.68 & 6.96 & 20.85 & 72.19 \\
\hline
\end{tabular}

Table 6: Monthly hydropower potential of Barekese Reservoir

\begin{tabular}{|c|c|c|}
\hline Month & Water Power Potential P (kW) & Power of hydropower plant $P_{H}(k W)$ \\
\hline April & 221.7 & 155.2 \\
\hline May & 515.9 & 361.2 \\
\hline June & 756.3 & 529.4 \\
\hline July & 457.1 & 320 \\
\hline September & 729.3 & 510.5 \\
\hline October & 478.8 & 335.2 \\
\hline Average & 526.5 & 368.6 \\
\hline
\end{tabular}

headwork only produced about $59,392 \mathrm{~m}^{3} /$ day as at 2010 (Kuma et al., 2010) which is only about $27 \%$ of the design capacity. This problem of underproduction of treated water could be attributed to two main factors: inadequate power to run the pumps and inadequate expansion of the water treatment infrastructure (Maoulidi, 2010, Antwi, 2005). The current average production of treated water at the headworks is $109,000 \mathrm{~m}^{3} /$ day.

Besides, the availability of facilities such as a penstock, a platform for the installation of a power generation turbine and excess water in the rainy season indicates the feasibility of operating a mini hydropower plant in the rainy season. GWCL could therefore consider the following options in order to maximize the water resource potential:

- Expanding the available facilities to treat more water for consumption
- Operating a mini hydro plant which could operate for six months of the year i.e. from April to July and from September to October.

From Table 6, the average monthly Water Power Potential, $\boldsymbol{P}$ and Power of Hydropower Plant, $\boldsymbol{P}_{\boldsymbol{H}}$, in the months of operation are $526.5 \mathrm{~kW}$ and $368.6 \mathrm{~kW}$ respectively. According to Arthur (2014) a typical $60 \mathrm{~kW}$ small-scale hydropower plant could serve about 365 household with an average of 5 persons per household. Therefore, from computation using the $368.6 \mathrm{~kW}$ power of the hydroplant at Barekese, the facility could serve about 2,242 household in the rainy season if implemented. In view of this, such a facility that generates electricity from excess water that would have otherwise been spilled will go a long way to add some amount of power to the national grid. 


\section{CONCLUSION AND RECOMMENDA- TIONS}

In this study, the assessment of the water balance of the Barekese Reservoir was performed using an integrated Remote Sensing and GIS approach for estimation of surface runoff based on SCS curve numbers.

Total watershed runoff and direct precipitation respectively constituted $94.32 \%$ and $5.68 \%$ of the inflows while spilled water, water withdrawal and evaporation respectively constituted $72.19 \%, 20.85 \%$ and $6.96 \%$ of the outflows. The current average production of treated water is $109,000 \mathrm{~m}^{3} /$ day but the reservoir can safely yield the design capacity of $220,000 \mathrm{~m}^{3} /$ day and an additional average hydropower of $368.6 \mathrm{~kW}$ in the rainy season. GWCL can maximize the water resource potential of the Barekese Reservoir by the implementation of the following options:

I. Expansion of facilities at the headworks to increase water supply

II. Operation of a mini hydro plant during the rainy season. This however should be subjected to economic analysis since the hydrological analysis is positive in the rainy season.

The power generation from the facility would alleviate the burden imposed on surrounding communities by the prevailing intermittent power outages in the country. Operation of the facility would also lead to the rapid socioeconomic development of the area.

There is observed increasing degradation of the vegetative land cover in the Barekese Catchment area. Between 1986 and 2007, the open forest has reduced by $44.9 \%$ while farmlands have increased by $30 \%$. Intensive education of the inhabitants and collaborative work among stakeholders is required to address the rate of forest degradation in the catchment area.

The Meteorological Stations at Offinso and Barekese should be reopened and furnished with the requisite equipment and personnel to enhance research study in the area. The spill from the reservoir should be monitored by setting up a hydrological gauge station downstream of the Barekese Dam or by periodic measurement of the head over the spillway.

\section{REFERENCES}

Adie, D. B., Ismail, A., Muhammad, M. M. and Aliyu, U. B. (2012). Analysis of the water resources potential and useful life of the Shiroro Dam, Nigeria. Nigerian Journal of Basic and Applied Science, 20(4): 341-348.

Acheampong, T. and Ankrah, F. (2014). Pricing and deregulation of the energy sector in Ghana: challenges and prospects. Ghana Energy Situation Report, Q1 2014.

Adu, S. V. (1992). Soils of the Kumasi Region, Ashanti Region, Ghana. Accra: Soil Research Institute, Advent Press.

Adwubi, A., Amegashie, B. K., Agyare, W. A., Tamene, L., Odai, S. N., Quansah, C. and Vlek, P. (2009). Assessing sediment inputs to small reservoirs in Upper East Region, Ghana. Lakes and Reservoirs: Research and Management, 14: 279-287.

Allen, R. G., Pereira, L. S., Raes, D. and Smith M. (1998). FAO Irrigation and drainage. Crop evapotranspiration - Guidelines for computing crop water requirements, Paper 56.

Andreini, M., van de Giesen, N., van Edig, A., Fosu, M. and Andah, W. (2000). Volta Basin Water Balance. ZEF - Discussion Papers on Development Policy, 21: 9-10.

Antwi, E. O. (2005). Drought preparedness plan for Kumasi Water Supply System. MPhil. (Civil Engineering) Thesis. Kwame Nkrumah University of Science and Technology Kumasi, Ghana. 
Water balance of the Barekese Reservoir ... 50

Arthur, J. K. (2014). Assessment of a typical small hydropower site for rural electrification in the Western Region of Ghana. MSc. (Renewable Energy Technologies) Thesis. Kwame Nkrumah University of Science and Technology Kumasi, Ghana.

Boakye, E., Odai, S. N., Adjei, K. A. and Annor, F. O. (2008). Landsat images for assessment of the impact of land use and land cover changes on the Barekese Catchment in Ghana. European Journal of Scientific Research, 22(2): 269-278.

British Hydropower Association (2012). A guide to UK mini-hydro developments, 3.

Chow, V. T., Maidment, D. R. and Mays, L. W. (1988). Applied Hydrology. Singapore: McGraw-Hill Book Company.

Dernedde, S. and Ofosu-Ahenkorah, A. K. (2002). Mini Hydro Power in Ghana: Prospects and Challenges. Energy Foundation Report, 20-21.

Gyampoh, B. A., Amisah, S., Idinoba, M. and Nkem, J. (2009). Using traditional knowledge to cope with climate change in rural Ghana. Unasylva, 231/232, 60.

Hooijer, A. and Track, S. (2009). Water Resources Study Kumasi. Ghana Water Company Ltd/Ballast Nedam.

Jothiprakash, V. and Garg, V. (2008). Re-look to conventional techniques for trapping efficiency estimation of a reservoir. International Journal of Sediment Research, 23(1): 76-84.

Kebede, S., Travi, Y., Alemayehu, T. and Marc, V. (2006). Water balance of Lake Tana and its sensitivity to fluctuations in rainfall, Blue Nile basin, Ethiopia. Journal of Hydrology, 316: 233-247.

Kuma, J. S., Owusu, R. O. and Gawu, S. K. Y.
(2010). Evaluating the Water Supply System in Kumasi, Ghana. European Journal of Scientific Research, 40(4): 506-514.

Kumasi, T. C., Obiri-Danso, K. and Ephraim, J. H. (2009). Land cover change in the Barekese River Basin of Ghana. Paper presented at Past Global Changes (PAGES) $1 \mathrm{~s} \mathrm{t}$ Young Scientists Meeting, Corvallis, USA, 6 -7 July.

Maoulidi, M. (2010). A water and sanitation needs assessment for Kumasi, Ghana. MCI Social Sector Working Paper, $N^{\circ}$ 16/2010.

Miller, V. B., Ramde, E. W., Gradoville, R. T. and Schaefer, L. A. (2011). Hydrokinetic power for energy access in rural Ghana. Renewable Energy, 36 : 671e675.

Shadeed, S. and Almasri, M. (2010). Application of GIS-based SCS-CN method in West Bank catchments. Palestine Water Science and Engineering, 3(1): 1-13.

Sumarauw, J. S. F. and Ohgushi, K. (2012). Analysis on curve number, land use and land cover changes and the impact to the peak flow in the Jobaru River Basin, Japan. International Journal of Civil \& Environmental Engineering IJCEE-IJENS, 12(02):17-23

Suphunvorranop, T. (1985). A guide to SCS runoff procedures. Technical Publication No. 85-5, Project Number 15/20 20003.

Turner, B. F., Gardner, L. R. and Sharp, W. E. (1996). The hydrology of Lake Bosumtwi, a climate-sensitive lake in Ghana, West Africa. Journal of Hydrology, 183:243-261.

USDA Soil Conservation Service (1972). National Engineering Handbook. Washington DC: US Government Printing Office, Hydrology Section 4.

Vörösmarty, C. J. and Sahagian, D. (2000). Anthropogenic disturbance of the terrestrial 
51 Anyemedu et al.

water cycle. BioScience, 50(9): 753-765.

Yeung, C. W. (2005). Rainfall-runoff and water - balance models for management of the Fena
Valley Reservoir, Guam. U.S. Geological Survey Scientific Investigations Report, 2004 $-5287$. 